\title{
The Snakes and Ladder on Speaking Ability in Children 5-6 Years
}

Ni Nyoman Ari Ratnadi ${ }^{1 凶}$, Kadek Devy Marleni ${ }^{2}$, Kadek Dwi Arlinayanti ${ }^{3}$

${ }^{1}$ Diploma of Midwifery, Sekolah Tinggi Ilmu Kesehatan Buleleng, Bali, Indonesia,

${ }^{2}$ Bachelor of Nursing, Sekolah Tinggi Ilmu Kesehatan Buleleng, Bali, Indonesia,

${ }^{3}$ Diploma of Midwifery, Sekolah Tinggi Ilmu Kesehatan Buleleng, Bali, Indonesia

$\bowtie$ email: ariratnadi@gmail.com

Received:

September 15, 2021

Revised:

November 04, 2021

Accepted:

December 20

2021

\section{ABSTRACT}

Early childhood is also called the golden age because children's physical and motor skills develop and grow rapidly, both in terms of emotional, intellectual, and moral development. The development of cognitive abilities is the development of basic skills to improve children's abilities, one of which is the ability to speak, especially the ability to speak English which is a development to become a bilingual school. Snakes and ladders is a game that is used as a game medium to improve cognitive development (speaking) in children where this game contains pictures of snakes and ladders as well as instructions in English that must be done which are divided into small boxes to connect one box to another. This study aimed to analyze the effect of Snakes and Ladders Game on English Speaking Ability in Children 5-6 Years at TK Negeri Pembina, Banjar District. This study used a pre-experimental design with a one-group pre-post test design, the sample size in this study was 38 respondents who were taken by using purposive sampling technique. This study used the Paired-t-test, the $p$ value $(0.00)<(0.05)$, it means that H0 was rejected and Ha was accepted. It concluded that there is an effect of Snakes and Ladders Game on English Speaking Ability in Children 5-6 Years at TK Negeri Pembina, Banjar District.

Keywords: Speaking Ability; Snakes and Ladders Game; Early Childhood.

\section{INTRODUCTION}

Early childhood is also called the golden age because children's physical and motor skills develop and grow rapidly, both in terms of emotional, intellectual, and moral development. This causes many parties to pay so much attention to the development of golden age children that it will not be repeated (Mursid, 2015).

Early Childhood Education (PAUD) is guidance aimed at children from birth to the age of six which is carried out through educational stimulation to help physical and spiritual growth and development so that children are ready to enter further education. With the coaching efforts given to children to develop the potential of children optimally. The possibility that can be developed includes the physical-motor, intellectual, moral, emotional, and spiritual development of children by taking into account the developmental factors of children as unique learning (Mursid, 2015).

Education of preschool children (pre-operational) is children 2-7 years and experiencing changes in cognitive function. In pre-operational children, they are able to 
use symbols by using words to remember their past and begin to change from egocentric to more rational. Early childhood education is applied by learning through playing (learning through playing) (Sujono, 2009).

Children's cognitive development includes the development of general knowledge abilities, scientific knowledge, the development of the concept of shape, color, size, and pattern, the concept of the development of numbers, symbols of numbers, and letters. Cognitive development is needed to support other developments, such as language development and other intelligence developments. A person's numeracy intelligence is characterized by his ability to recognize numbers, think logically and scientifically, be consistent in thinking, and be able to interact with numbers (Dadan, 2016).

To improve the cognitive development of children, it is necessary to use game media that will be played with children, of course, it has benefits for cognitive development in children that are interesting and provide interest for children. Many popular games can be used to improve speaking skills in children.

Many games that can be used to improve cognitive abilities in children are snakes and ladders. Snakes and ladders games can provide learning motivation for children so that they always learn or repeat the material that has been studied previously which will later be tested through games so that it feels fun for children. The game of snakes and ladders requires space because it has a length and width so it will make it easier for children to learn by using the game. The game board is divided into small squares and in some of the boxes are drawn a number of ladders and snakes that connect them to other squares (Ani, 2010).

Based on some of the opinions above, it can be concluded that speaking intelligence can develop the ability to process words. By learning to speak English, not only children's speaking skills can be developed but other skills can also be developed such as listening and reading. Therefore, speaking is excellent to be applied from an early age to children. The ability to speak can support the next child's learning and is a much prioritized academic intelligence.

\section{METHOD}

This research is a pre-experimental study with the design of One Group Pre-test Post-test, where before being given the treatment, the pre-test is carried out first, and then after the treatment is given the post-test. This research design does not use a comparison group (control), but observations have been made before giving an action (pre-test) that allows changes after the experiment.

The design of this research can be described as follows:

\section{Schematic 1 One Group Pre-Test Post-Test Design}

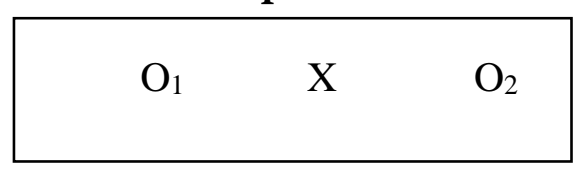

Notes :

O1 : Pretest before playing snake and ladder 
O2 : Posttest after playing snake and ladder

$\mathrm{X}$ : Snake and ladder game treatment

The hypotheses in this study are:

$\mathrm{Ha}$ : There is an Effect of Snakes and Ladders Game on the English Speaking Ability of Children 5-6 years in TK Negeri Pembina, Banjar District.

H0 : Snakes and Ladders Game has no effect on the English Speaking Ability of Children 5-6 years in TK Negeri Pembina, Banjar District.

In this study, the variables studied were the game of snakes and ladders as the independent variable and the child's numeracy ability as the dependent variable. The population in this study was children 5-6 years in TK Negeri Pembina, Banjar District with a total of 38 people. In this study, the samples taken were children aged 5-6 years in TK Negeri Pembina, Banjar District, which was considered to represent the population according to the inclusion and exclusion criteria. The sampling technique used is non-probability sampling with purposive sampling technique. This research will be conducted at TK Negeri Pembina, Banjar District, Buleleng Regency, Bali for 3 weeks. The data collection tool used in this study was the Denver II observation sheet for measuring speaking skills and the SAP game of snakes and ladders. The observation sheet contains sample demographic data and measurement of speaking ability. In the demographic data, respondents consist of name, age, class, and gender. The SAP game of snakes and ladders contains the implementation procedure for performing the ladder game in the form of a step-by-step game. At the same time, the measurement of speaking ability uses the Denver II assessment format as an observation sheet to determine the speaking ability of children aged 5-6 years.

\section{FINDINGS AND DISCUSSION}

Learning activities measure the ability to speak in children carried out by children aged 5-6 years in Denver II and then recorded in the observation sheet. In this study, the researcher wanted to know the ability to speak English in children 5-6 years before (Pretest) and after (Post-test) given through the game of snakes and ladders. The table below shows the score of English speaking skills before being given the snake and ladder game activity.

Table 1. Identification of English Speaking Ability Before Getting Snakes and Ladders Game in Children 5-6 Years at TK Negeri Pembina, Banjar District

\begin{tabular}{ccccccc}
\hline Variable & N & Average & Min & Maks & SD & $\begin{array}{c}\text { CI } \\
\mathbf{9 5 \%}\end{array}$ \\
\hline $\begin{array}{c}\text { English } \\
\text { speaking } \\
\text { ability }\end{array}$ & 34 & 4,97 & 2 & 8 & 1,660 & $\begin{array}{c}4,39- \\
5,55\end{array}$ \\
\hline
\end{tabular}


The table above shows that the average score of English speaking ability before getting the snake and ladder game for children aged 5-6 is 4.97 . The lowest score of English speaking ability is on a scale of 2, and the highest is 8 .

The score of English speaking ability after being given the snake and ladder game can be seen in the table below

Table 2. Identification of English Speaking Ability After Getting the Snakes and Ladders Game in Children 5-6 Years at TK Negeri Pembina, Banjar District

\begin{tabular}{ccccccc}
\hline Variable & N & Average & Min & Maks & SD & CI 95\% \\
\hline $\begin{array}{c}\text { English } \\
\text { speaking } \\
\text { ability }\end{array}$ & 34 & 6,26 & 3 & 9 & 1,639 & $5,69-6,84$ \\
\hline
\end{tabular}

Table 2 shows that the average value of English speaking ability after getting the snake and ladder game for children 5-6 years is 6.26. The lowest English speaking ability score is 3 , and the highest is 9 .

Table 3 Analysis of the Effect of Snakes and Ladders Game on English Speaking Ability in Children 5-6 Years at TK Negeri Pembina, Banjar District

\section{Paired Differences}

\section{Intervention Group}

$$
\text { N Mean } \pm \text { SD } \quad \begin{gathered}
\text { Difference } \\
(\text { Mean } \pm \text { SD })
\end{gathered}
$$

\begin{tabular}{|c|c|c|c|c|c|}
\hline \multirow{2}{*}{$\begin{array}{l}\text { English } \\
\text { speaking } \\
\text { ability }\end{array}$} & Pre-test & \multirow{2}{*}{34} & $4,97 \pm 1,660$ & \multirow{2}{*}{$-1,294 \pm 0,719$} & \multirow{2}{*}{0,000} \\
\hline & Post-test & & $6,26 \pm 1,639$ & & \\
\hline
\end{tabular}

Table 3 shows that there are differences in pre and post-data on the ability to speak English before and after being given the snake and ladder game by getting a $p$-value of 0.000 so that the $p$-value $<0.05$. There is a significant effect of playing snakes and ladders on the ability to speak English in children aged 5-6 years at TK Negeri Pembina, Banjar District.

The results showed that from 34 respondents the average value of English speaking ability before getting the snake and ladder game in children 5-6 was 4.97 with a good English speaking ability score of 7 people (20.6\%), the value of English speaking ability English is sufficient for 12 people (35.3\%), the value of English speaking ability is less than 13 people (38.2\%), the value of English speaking ability is very less than 2 people (5.9\%) with the lowest score of English speaking ability is the scale is 2 and the highest is 8 . Based on the description of the ability to speak English before getting the snake and ladder game, most children 5-6 years have a less category, namely 13 people with a percentage of $38.2 \%$. 
Children 5-6 years are at one stage of cognitive development, namely preoperational which allows children to still think symbolically. Children can assume from what they see. Children still use some symbols or words and pictures to understand something they see (Permadi, 2018).

The results of the study on the effect of the snake and ladder game on the ability to speak English showed that there were differences in pre and post data on the ability to speak English before and after being given the snake and ladder game by getting a pvalue of 0.000 so that the $p$-value $<0.05$. That is, there is a significant effect of playing snake and ladder on the ability to speak English in children 5-6 years at TK Negeri Pembina, Banjar District.

Snakes and ladders games have various benefits for children's development in developing abilities, sharpening logic, and improving concentration skills. According to Sugiwati (2017) this game can improve intelligence and introduce vocabulary in learning foreign languages, especially English for kindergarten children.

Therefore, teachers should be able to create or use games in teaching speaking English to develop children's speaking skills. There are many basic concepts that early childhood can learn in speaking English. Knowledge of speaking is much easier to acquire through play activities. Kindergarten-aged children have a limited attention span and are still difficult to manage. Still, if a foreign language is introduced while playing, the child will feel happy; without realizing it, the child has learned a foreign language, especially English. With this, the child's ability, especially speaking English, will increase because the teacher develops language learning following the principles of speaking and introducing new vocabulary.

\section{CONCLUSION}

This snake and ladder game really supports the child's right and left brain development. Through this game children can also know how to learn to solve problems. Because two or more children can play it, this game helps teach children how to work together by waiting their turn. More importantly, this game can stimulate children to remember vocabulary in a foreign language. The reason is that in this game, children are required to be able to memorize vocabulary and speak in English based on the instructions in the snake and ladder game box. According to the results obtained for speaking English in kindergarten children, the researchers suggest that PAUD, kindergarten and elementary schools make the snake and ladder game the proper method to be given to early childhood to stimulate the ability to speak foreign languages. children, especially English.

\section{ACKNOWLEDGMENTS}

The researcher would like to thank the principal, teachers, and students at TK Negeri Pembina, Banjar District, for their cooperation in conducting this research to solve students' difficulties in learning foreign language vocabulary, especially English. 


\section{REFERENCES}

Aisyah, S. (2015). Perkembangan dan Konsep Dasar Pengembangan Anak Usia Dini. (E. Purwanto, Ed.) (1st ed.). Tangerang Selatan: Universitas Terbuka

Ani, Ismayani. (2010). Fun Math with 2 Children. Jakarta: PT Elek Medika Komputindo

Aprinawati, I. (2017). Penggunaan Media Gambar Seri Untuk Meningkatkan Kemampuan Berbicara Anak Usia Dini Iis, Jurnal obsesi 1(2), 148-155

Dadan, Suryana. (2016). Stimulasi \& Aspek Perkembangan Anak. Jakarta: Kencana

Harmer, J. (2002). The Practice of English Language Teaching. New York. Longman

Kementrian Pendidikan dan Kebudayaan. (2017). Statistik Pendidikan Anak Usia Dini 2016/2017 [Early Childhood Education Statistics 2016/2017], 1-119. Retrieved from http://publikasi.data.kemdikbud.go.id/uploadDir/isi_C6C3980D-F1F1- 4BEB-8DFAFD57559F1D86.pdf

Mawadah, Arty Nur \& Muniroh Munawar Mun. (2018). Analisi Peran Ibu Bekerja Dalam Perkembangan Bicara Anak Usia TK B, 3367(2), 56-61

Mursid. (2015). Pengembangan Pembelajaran Paud. Bandung: Pt Remaja Rosdakarya

Permadi, H. (2018). Pengembangan Permainan Ular Tangga Untuk Meningkatkan Kemampuan Berhitung Permulaan Anak Usia 5-6 Tahun.

Putriyani. (2012). Tumbuh Kembang Anak Usia Dini, 1110029

Rahman, U. (2018). Karakteristik Perkembangan Anak Usia Dini. Lentera Pendidikan : Jurnal Ilmu Tarbiyah Dan Keguruan, 12(1), 46-57. https://doi.org/10.24252/lp.2009v12n1a4

Soetjiningsih, \& Ranuh, G. (2013). Tumbuh Kembang Anak. (Y. J. Suyono, Ed.) (2nd ed.). Jakarta: EGC

Sugiwati. (2017). Metode Bermain Ular Tangga Untuk Meningkatkan Perkembangan Kognitif Kelompok A Di Tk. Ria Baruk Utara Viii/35 Rungkut - Surabaya. Pg Paud, Fip, Unesa

Sugiyono. (2016). Metode Penelitian Kuantitatif, Kualitatif, dan $R \& D$. Bandung: Alfabeta Sujono, Riyadi. (2009). Asuhan Keperawatan Pada Anak. Yogyakarta: Graha Ilmu 